Studia Oecumenica 17 (2017)

DOI: $10.25167 / \mathrm{SOe} / 17 / 2017 / 419-438$

PAWE⿺ BRUdeK

Instytut Psychologii KUL

\title{
Protestancka Szwecja jako kolebka teorii gerotranscendencji Larsa Tornstama. Pochodzenie, ogólny zarys i krytyczna analiza koncepcji
}

\author{
Protestant Sweden as a Cradle \\ of Lars Tornstam's Gerotrascendence Theory. \\ Origin, General Brief and Critical Analysis of the Conception
}

\begin{abstract}
Summary
In terms of adaptation to old age, older people are not homogeneous. It is emphasized in psychological literature that optimal adaptation is most often accompanied by the sustenance and/or increase in satisfaction with life as well as the positive realization of late adulthood development tasks. There are many theories explaining the process of adaptation to old age. One of them, still little understood and developed in the circle of Polish psychologists, is the concept of gerotranscendancy coined by Lars Tornstam. This concept has been enjoying great interest among researchers from Scandinavian countries and is a cognitively valuable and inspirational approach to positive aging. It also allows to reconsider the process of aging as well as the seniors themselves. This article presents the origins of the gerotranscendence theory, its theoretical foundations and main assumptions, as well as its critical analysis (the strengths and weaknesses of theory).
\end{abstract}

Keywords: gerotranscendence, Zen Buddhist metaphor, meta-space paradigm, seniors.

\section{Streszczenie}

Pod względem adaptacji do starości osoby starsze nie stanowią jednorodnej grupy. W literaturze psychologicznej podkreśla się, że optymalnemu przystosowaniu towarzyszy najczęściej utrzymanie lub/i wzrost satysfakcji z życia oraz pozytywne rozwiązanie zadań rozwojowych przypadających na okres późnej dorosłości. Na gruncie nauk społecznych funkcjonuje wiele teorii wyjaśniających proces adaptacji do starości. Jedną z nich - wciąż w małym stopniu poznaną i opracowaną w kręgu psychologów polskich - jest koncepcja gerotranscendencji autorstwa Larsa Tornstama. Koncepcja ta cieszy się dużym zainteresowaniem badaczy z kręgu krajów skandynawskich i stanowi poznawczo wartościową i inspirującą koncepcję pozytywnego starzenia się. Pozwala ona bowiem w nowy sposób ująć proces starzenia się i spojrzeć na człowieka starego. Artykuł prezentuje pochodzenie teorii gerotranscendencji, jej teoretyczne podstawy i główne założenia oraz krytyczną analizę (mocne i słabe strony teorii). 
Słowa kluczowe: gerotranscendencja, metafora buddysty Zen, metaparadygmat kosmiczny, seniorzy.

Uniwersytet w Uppsali - miasta położonego nieopodal Sztokholmu i będącego dawną stolicą Szwecji - to najstarszy uniwersytet w Skandynawii. Został on utworzony w 1477 r. z inicjatywy ówczesnego prymasa Kościoła katolickiego w Szwecji, abpa Jakoba Ulvssona, i funkcjonuje po dzień dzisiejszy, pozostając jednym z najbardziej znanych uniwersytetów w Europie ${ }^{1}$. Dla gerontologów, socjologów i psychologów, zajmujących się na co dzień naukowym namysłem nad finalnym etapem życia człowieka, kojarzony jest głównie z osobą nieżyjącego już Larsa Tornstama - socjologa, a zarazem autora jednej z teorii adaptacji do starości, określanej w literaturze mianem teorii gerotranscendencji ${ }^{2}$.

Teoria ta została sformułowana bez mała 30 lat temu i cieszy się - głównie w krajach skandynawskich, choć nie tylko - dużym zainteresowaniem w środowisku gerontologów, zarówno teoretyków, jak i praktyków3. Teoria gerotranscendencji coraz częściej bowiem staje się podstawą szeroko zakrojonych oddziaływań pomocowych adresowanych do seniorów w zakresie satysfakcji z życia, aktywności społecznej, religijności i duchowości oraz opieki zdrowotnej ${ }^{4}$. Warto zauważyć, że na gruncie polskim niewiele jest publikacji naukowych, traktujących tę koncepcję jako „zaplecze” teoretyczne dla realizowanych badań empirycznych ${ }^{5}$. Można natomiast odnaleźć opracowania wzmiankujące o tej koncepcji lub zawierające syntetyczną prezentację głównych jej założeń ${ }^{6}$. Tymczasem,

${ }^{1}$ H. DE Ridder-Symoens, A History of the University in Europe, Cambridge 2003, 84.

2 Zob. L. Tornstam, Gerotranscendence: A Developmental Theory of Positive Aging, New York 2005.

${ }^{3}$ Zob. J. Liang, Components of a Meaningful Retirement Life - A Phenomenological Study of the 1950 Birth Cohort in Urban China, ,Journal of cross-cultural gerontology” 26 (2011) 3, 279298; B. WADENSTEN, The theory of gerotranscendence as applied to gerontological nursing - Part I, „International Journal of Older People Nursing” 4 (2007) 2, 289-294; B. WADENSTEN, M. CARLSSON, The theory of gerotranscendence in practice: guidelines for nursing - Part II. „International Journal of Older People Nursing" 4 (2007) 2, 295-301; B. Wadensten, M. CARLsson, Theory driven guidelines for practical care of older people, based on the theory of gerotranscendence, „Journal of Advanced Nursing" 41 (2003) 5, 462-470; F.A. LewIN, L.E. THOMAS, Gerotranscendence and Life Satisfaction: Studies of Religious and Secular Iranians and Turks, „Journal of Religious Gerontology" 12 (2001) 1, 17-41.

${ }^{4}$ Zob. P. BRUDEK, Larsa Tornstama Teoria Gerotranscendencji jako teoria pozytywnego starzenia się, „Psychologia Rozwojowa” 21 (2016) 4, 14-18.

${ }^{5}$ Zob. TENŻE, Podmiotowe korelaty satysfakcji z matżeństwa osób w okresie późnej dorostości, Lublin 2015 (praca dr. w BKUL).

${ }^{6}$ Zob. P. BRUDEK, S. STEUDEN, Religijne korelaty zadowolenia z matżeństwa w okresie późnej dorostości, w: P. Brudek, S. Steuden, I. Januszewska, A. Gamrowska (red.), Oblicza starości we wspótczesnym świecie. Perspektywa psychologiczno-medyczna, Lublin 2015, 15-44; P. BRUDEK, Rola dziadków $w$ procesie wspierania rozwoju dziecka $w$ prenatalnym okresie życia z perspektywy teorii gerotranscendencji Larsa Tornstama, w: E. LichtenberG-KoKoszKa, E. JANIUK, P. KierPaL (red.), Prenatalny okres życia człowieka. Zagadnienie interdyscyplinarne, Kraków 2014, 109-126; P. BRUDEK, G. CIUŁA, Hierarchia wartości a satysfakcja ze związku matżeńskiego u osób w okresie 
jak zauważa Barbro Wadensten, teoria ta prezentuje nowy sposób rozumienia procesu starzenia się, dzięki czemu stanowi wartościową perspektywę badawczą, stwarzającą realną szansę uchwycenia faktycznej dynamiki rozwoju w jego schyłkowej fazie?

Mając na uwadze powyższe spostrzeżenia, głównym celem prezentowanego artykułu uczyniono charakterystykę teorii gerotranscendencji od strony jej ontologicznych założeń. W pierwszej kolejności, dla ukazania aktualności problematyki starości, zostaną omówione główne trendy zmian demograficznych w odniesieniu do krajów Unii Europejskiej, w tym także Polski. Następnie zostaną przedstawione jej podstawy teoretyczne. W dalszej kolejności zostanie zaprezentowana definicja i struktura procesu gerotranscendencji. Na końcu zostaną omówione mocne i słabe strony prezentowanej teorii.

\section{Starość wyzwaniem dla współczesnej psychologii}

Obecnie jesteśmy świadkami dynamicznie postępującego procesu starzenia się ludności. W rezultacie tego procesu wzrasta odsetek osób starszych (60 lat i więcej) w globalnej populacji. Za prawdziwością tego stwierdzenia przemawia nie tylko zdroworozsądkowa analiza rzeczywistości, ale przede wszystkim „twarde” dane statystyczne ${ }^{8}$. Ekonomiści oraz demografowie szacują, że populacja mieszkańców Europy, stanowiąca około 10\% ludności świata, w drugiej połowie obecnego stulecia zmniejszy się do $5 \%{ }^{9}$. Na podstawie raportu Eurostatu (Statistical Office of the European Union) z 2011 r. zatytułowanego: Demography Report 2010. Older, More Numerous and Diverse Europeans można stwierdzić, że w 27 państwach Unii Europejskiej (UE) w styczniu 2010 r. żyło 501,1 mln ludzi. W ogóle ludności UE udział osób w wieku 65 lat i więcej wynosił 17,4\% i był większy w porównaniu z 1990 r. o 3,7\%. Prognozuje się, że udział seniorów w populacji UE w 2040 r. osiągnie wskaźnik 20\%, a w 2060 r. będzie wynosił

późnej dorostości, SSHT 46 (2013) 2, 368-382; P. BRUdEK, S. STEUDEN, Znaczenie osób starszych w procesie ksztattowania dojrzałej osobowości z perspektywy teorii gerotranscendencji Larsa Tornstama, (referat wygłoszony na Ogólnopolskiej Konferencji Naukowej: „Wychowanie, kształtowanie, formowanie. Czy współczesna pedagogika poradzi sobie bez duchowości?”, Sieradz 2012); E.H. ERIKSON, J.M. ERIKSON, Dopetniony cykl życia. Wersja rozszerzona o nowe rozdziaty autorstwa Joan M. Erikson poświęcone dziewiatemu etapowi rozwoju osobowości człowieka, Gliwice 2012; M. MALEC, Gerotranscendencja - teoria pozytywnego starzenia się. Założenia i znaczenie, w: M. Olejarz (red.), Dyskursy młodych andragogów, Zielona Góra 2012, 45-60.

${ }^{7}$ B. WAdENSTEN, Introducing Older People to the Theory of Gerotranscendence, ,Journal of Advanced Nursing" 52 (2005) 4, 381.

8 Department of Economic and Social Affairs Population Division, World Population Aging 2015, New York 2015.

9 J. SzYMAŃcZAK, Starzenie się polskiego spoleczeństwa - wybrane aspekty demograficzne, „Studia BAS. Starzenie się społeczeństwa polskiego” 30 (2012) 2, 9-28. 
$30 \%$. Proces starzenia się populacji w państwach UE przebiega w różnym tempie. Szacuje się, że w krajach, w których odsetek ludzi starszych jest najwyższy, takich jak np. Niemcy czy Włochy, proces starzenia się ludności przez kolejnych dwadzieścia lat będzie odznaczał się znacznym dynamizmem, a następnie ustabilizuje się. Natomiast kraje, głównie we wschodniej części UE, w których strukturze społecznej obserwuje się obecnie największy udział młodszych grup wiekowych, będą starzeć się coraz szybciej, a do 2060 r. będą stanowiły najstarsze społeczności UE.

Proces starzenia się polskiego społeczeństwa wyraźnie uwidocznił się z początkiem lat 90. minionego wieku ${ }^{10}$. Był on ściśle związany z transformacją ustrojową kraju, która zapoczątkowała wiele znaczących zmian w zakresie zachowań demograficznych ludności. W 1990 r. osoby, które liczyły 60 lat lub więcej, stanowiły 12,8\% ogółu ludności. W 2010 r. wskaźnik ten wynosił 16,7\%, a w 2011 r. osiągnął już wartość równą 17,3\% ${ }^{11}$. Zgodnie z przyjętymi założeniami Prognozy ludności na lata 2008-2035, sporządzonej przez Departament Badań Demograficznych Głównego Urzędu Statystycznego (GUS) w 2009 r., zmiany w zakresie intensywności urodzeń oraz zgonów doprowadzą do pogłębiania się ujemnego przyrostu naturalnego. Przewiduje się, że w 2035 r. nadwyżka zgonów nad urodzeniami zbliży się do 180 tys. W okresie objętym prognozą przeciętne trwanie życia w Polsce będzie nadal wydłużało się, osiągając w 2035 r. wartości większe, w odniesieniu do 2007 r., o 6 lat dla mężczyzn i 3 lata dla kobiet. Czas wydłużania się przeciętnego trwania życia, przy jednoczesnym niskim poziomie dzietności, będzie generował niekorzystne zmiany w strukturze wieku ludności, przejawiające się pogłębianiem procesu starzenia się społeczeństwa. Wyniki prognozy sygnalizują zdecydowane obniżenie udziału najmłodszych generacji w strukturze społecznej ogółem do 2035 r. Redukcja udziałów dzieci i dorosłych w strukturze demograficznej będzie skutkowała wzrostem odsetka ludzi starszych, który w końcu horyzontu prognozy wzrośnie o ponad $10 \% \mathrm{w}$ miastach i $8,4 \%$ na wsi.

Zasygnalizowane wyżej zmiany demograficzne stają się palącym wyzwaniem nie tylko w obszarze polityki społecznej czy ekonomicznej, ale także na gruncie psychologii ${ }^{12}$. Starość bowiem obok nowych jakości rozwojowych, których trafną egzemplifikacją jest kategoria mądrości ${ }^{13}$, przynosi ze sobą również szereg dojmu-

10 Rzaddowa Rada Ludnościowa, Sytuacja demograficzna Polski. Raport 2009-2010, Warszawa $2010,29$.

${ }_{11}$ M. Rackaw, M. Rosochacka-Gmitrzak, Proces starzenia się, w kontekście wyzwań demografii, polityki społecznej oraz doniesień badawczych, Warszawa 2012.

12 Zob. P. Brudek, S. Steuden, Wstęp, w: P. Brudek, S. Steuden, I. JanuszewsKa, A. GamrowSKA (red.). Oblicza starości we wspótczesnym świecie, 7-11.

${ }^{13}$ M. Ardelt, Wisdom, age, and well-being, w: K.W. Schaie, S.L. Willis (red.), Handbook of the psychology of aging, Amsterdam 2011, 279-291; por. Ł. FLorCZYK, P. BRUdEK, S. STEUden, Mądrość jako przymiot starości. Perspektywa biblijna, „Forum Teologiczne” 17 (2016), 55-71; 
jących problemów i związanych z nimi zagrożeń ${ }^{14}$. W opinii Stanisławy Steuden do najważniejszych z nich należą: (1) trudności związane z podejmowaniem i realizacją codziennych zadań; (2) nienadążanie za postępem naukowo-technicznym; (3) brak zrozumienia ze strony innych osób, także członków najbliższej rodziny; (4) konieczność zmiany mieszkania podyktowana względami finansowymi lub barierami architektonicznymi; (5) negatywny bilans dotychczasowego życia; (6) doświadczanie wielorakich negatywnych zdarzeń życiowych związanych ze stratą multiplikacja strat. Stawianie czoła tym trudnościom i skuteczne radzenie sobie z nimi (a nie radzenie sobie w ogóle, bo każdy sobie jakoś radzi, niekoniecznie odwołując się do strategii pozytywnych - efektywnych, prorozwojowych) stanowi jedno z kluczowych zadań okresu późnej dorosłości ${ }^{15}$. Funkcjonujące w literaturze psychologicznej teorie adaptacji do starości, takie jak np.: teoria selektywnej optymalizacji z kompensacją (selective optimization with compensation) Paula Baltesa oraz jego współpracowników ${ }^{16}$; teoria społeczno-emocjonalnej selektywności (socioemotional selectivity theory) Laury Carstensen ${ }^{17}$ czy teoria gerotranscendencji (theory of gerotranscendence) Larsa Tornstama ${ }^{18}$, stanowią próbę wyjaśnienia sposobu realizacji tego zadania przez jednostkę ${ }^{19}$. Ostatnia z przywołanych propozycji - teoria gerotranscendencji - zasługuje na wyraźne zauważenie głównie dlatego, iż nie skupia się ona „na tym, czym starszy wiek jest faktycznie, ale na tym, jaki może on się stać”20. Pozwala tym samym nie tylko (z konieczności) zatroszczyć się o starość, ale przede wszystkim dostrzec i uaktywnić drzemiący w niej potencjał, a w rezultacie pomóc osobie starszej wykorzystać, mówiąc nieco poetycko, podarowany jej (wszak nie każdy dożywa wieku starczego) czas „ostatniej szansy

S. Steuden, P. Brudek, Ł. Florczyk, Madrość jako efekt pozytywnego starzenia się. Perspektywa psychologiczna, „Forum Teologiczne” 17 (2016), 73-87; S. STEUden, Z rozważań nad madrościa, w: I. UlfiK-Jaworska, A. Gata (red.), Dalej w tę sama stronę. Księga Jubileuszowa dedykowana Profesor Marii Braun-Gatkowskiej, Lublin 2012, 533-548; L. ZaJĄC-LAMPARsKA, Wspomaganie funkcjonowania ludzi starzejacych się, w: J. TremPata (red.), Psychologia rozwoju człowieka, Warszawa 2011, 419-431.

${ }^{14}$ M. Straś-Romanowska, Późna dorostośćc, w: J. Trempala (red.), Psychologia rozwoju czlowieka, 326-350.

15 S. Steuden, Psychologia starzenia się i starości, Warszawa 2011, 25.

16 P.B. Baltes, F. Dittmann-Kohl, R.A. Dixon, New perspectives on the development of intelligence in adulthood: Toward a dual-process conception and a model of selective optimization with compensation, „Life-Span Development and Behavior” 6 (1984), 33-76; P.B. BALTES, M.M. BALTES, Psychological perspectives on successful aging: The model of selective optimization with compensation, „Successful aging: Perspectives from the Behavioral Sciences” 1 (1990) 1, 1-34.

17 L.L. CARSTENSEn, Social and emotional patterns in adulthood: support for socioemotional selectivity theory, „Psychology and Aging” 3 (1992), 331-338.

${ }^{18}$ L. TORnSTAM, Gerotranscendence: a metatheoretical reformulation of the disengagement theory, ,Aging: Clinical and Experimental Research” 1 (1989) 1, 55-63.

19 Zob. S. Steuden, Psychologia starzenia się, 71-81.

${ }^{20}$ Tamże, 81. 
rozwojowej”21. Innymi słowy, zaproponowana przez L. Tornstama koncepcja adaptacji do starości stwarza realną szansę na to, aby w starzeniu się dostrzec niepowtarzalną przygodę życia, które wciąż trwa ${ }^{22}$.

\section{U źródel teorii gerotranscendencji}

Teoria gerotranscendencji powstała na przełomie lat 80 . i 90. minionego stulecia $\mathrm{w}$ odpowiedzi na rozbieżności zaistniałe pomiędzy ówczesnymi poglądami rozwijanymi na gruncie gerontologii społecznej a rezultatami badań empirycznych prowadzonych w obrębie populacji osób starszych. U jej źródeł legły kontrowersje będące następstwem opublikowania w 1961 r. przez Elaine Cumming i Williama Henry'ego podstawowych założeń teorii wycofania się (disengagement theory). Teoria ta zakładała wrodzoną skłonność do izolowania i wycofywania się osób starszych, której towarzyszą tendencje społeczne do odrzucania starzejących się jednostek. W myśl teorii, jednostka miała sukcesywnie zrywać więzi łączące ją ze społeczeństwem i w coraz większym stopniu skupiać się na swoim wnętrzu. Zakładano, że ten dwukierunkowy proces ma charakter nieunikniony i adaptacyjny zarówno dla jednostki, jak i dla społeczeństwa. Zgodnie z teorią, wycofywanie się osoby z życia społecznego nie pociąga za sobą niezadowolenia lub zaburzeń psychicznych. Wręcz przeciwnie - ponieważ postuluje się, iż wycofanie się ma charakter naturalnego procesu wolnego od uwarunkowań kulturowych, towarzyszy mu wzrost satysfakcji z życia oraz osiągnięcie wewnętrznej harmonii ${ }^{23}$.

Bazowe założenia teorii wycofania się umożliwiły jej autorom sformułowanie trzech zasadniczych postulatów (hipotez). W myśl pierwszego z postulatów wszystkie społeczeństwa w jakiś sposób odtrącają starzejącą się jednostkę. Druga hipoteza głosiła, że osoba powodowana wewnętrznymi siłami oddala się od społeczeństwa. To oddalanie się jednostki posiada zarówno społeczny, jak i psychologiczny charakter. Wycofanie społeczne dotyczy redukcji więzi i ról społecznych oraz ilości czasu poświęcanego każdej z pełnionych ról. Z kolei wycofanie się w wymiarze psychologicznym obejmuje znaczące zmniejszenie zaangażowania emocjonalnego $\mathrm{w}$ relacjach $\mathrm{z}$ innymi ludźmi i społeczeństwem jako takim oraz skierowanie się ku własnemu wnętrzu. Zgodnie z trzecim postulatem jednostka, pomimo wycofania społecznego i psychicznego, w dalszym ciągu ma możliwość doświadczania satysfakcji z życia. Oznacza to jednocześnie, że w sytuacji naruszenia naturalnego procesu wycofywania się, poprzez

\footnotetext{
21 M. Straś-Romanowska, Późna dorosłość, 326.

${ }^{22}$ Por. D. Quinodoz, Starzenie się - przygoda życia, która trwa, Warszawa 2014.

${ }^{23}$ L. Tornstam, Gerotranscendence: A Developmental Theory, 31-35.
} 
zmuszenie osoby starszej do aktywności, następuje u niej wyraźny spadek poczucia szczęśsia ${ }^{24}$.

Wszystkie trzy wyżej wymienione postulaty były przedmiotem burzliwej naukowej debaty, w którą zaangażowało się wielu gerontologów. W rezultacie osiągnięto konsensus, co do tego, że społeczeństwa zachodnie alienują i odrzucają ludzi starszych. Warto podkreślić, że ów konsensus okazał się jedynym niepodważalnym argumentem przemawiającym za słusznością teorii wycofania się. Drugi z postulatów, utrzymujący, że jednostka oddala się od społeczeństwa, został wyraźnie zakwestionowany także przez L. Tornstama. Uznano, iż nie ma empirycznych podstaw, aby uzasadnić występowanie wrodzonego zjawiska wycofania się osoby. Szczególnie intensywnie eksplorowany przez badaczy był trzeci postulat. Poszukiwano kluczowego czynnika (aktywność versus wycofanie się) satysfakcji z życia osób w podeszłym wieku. W ostatecznym rozrachunku przyjęto z dogmatyczną pewnością, jak podkreśla L. Tornstam, że jedynym predyktorem udanego życia w starości jest pobudzanie osoby do aktywnego angażowania się w działania dotyczące różnych obszarów życia ${ }^{25}$.

Postulaty wysuwane przez E. Cumming i W. Henry’ego wyraźnie zakwestionowały zatem elementarne założenia, cieszącej się wówczas powszechnym uznaniem badaczy, teorii aktywności (activity theory), zgodnie z którą mobilizowanie seniorów do podejmowania różnorodnych działań stanowi najprostszą drogę do podnoszenia ich satysfakcji z życia. Dało to początek, co sygnalizowano wyżej, burzliwej naukowej debacie, która w latach 60. i 70. XX w. zdominowała środowisko gerontologów. W efekcie teoria wycofania doczekała się licznych modyfikacji oraz reinterpretacji. Ważną rolę w tym procesie odegrał L. Tornstam wsparty na XI Międzynarodowym Kongresie Gerontologicznym, odbywającym się w Tokio w 1978 r., przez polskiego gerontologa Jerzego Piotrowskiego, który wyznawał pogląd, że za teorią wycofania się stoi być może jakaś podstawa teoretyczna, której warto poszukiwać w gąszczu pytań i empirycznych nieścisłości ${ }^{26}$.

Dodatkową inspirację do podjęcia metarefleksji nad teorią wycofania się czerpał L. Tornstam z wyników autorskich badań, które wyraźnie sugerowały, że niektóre aspekty teorii wycofania się pozwalają na trafną interpretację procesu adaptacji jednostki do zmian związanych ze starzeniem się. Okazało się bowiem, wbrew powszechnie uznawanym założeniom, że poziom samotności w badanej próbie maleje $\mathrm{z}$ każdą kolejną grupą wiekową, pomimo utraty pełnionych ról oraz bliskich osób. To młodzi badani, a nie starsi, wykazywali wysoki poziom

\footnotetext{
24 Tami̇e, 32-33.

25 Tamże, 33-34.

26 Tamże, 34.
} 
samotności. Wykazano ponadto, że rola interakcji społecznych z innymi ludźmi jako lekarstwo na samotność maleje z każdą kolejną grupą wiekową ${ }^{27}$.

Odwołując się do powyższych ustaleń oraz odnosząc się do literatury przedmiotu, L. Tornstam nakreślił zarys alternatywnej teorii starzenia się, którą określił mianem teorii gerotranscendencji.

\section{Czym jest gerotranscendencja?}

Pytanie, będące zarazem tytułem niniejszego paragrafu, bez wątpienia uznać należy za kluczowe dla analiz prowadzonych w obszarze gerotranscendencji. Autor omawianej teorii definiuje gerotranscendencję jako „zmianę metaperspektywy z postrzegania materialnego i racjonalnego na postrzeganie bardziej kosmiczne i transcendentne, skutkujące zazwyczaj zwiększeniem satysfakcji z życia"28. Wydaje się, iż najważniejszym fragmentem przywołanej definicji jest „zmiana metaperspektywy". W tym miejscu pomocny w dalszej lekturze może okazać się nieco szerszy komentarz. Otóż owa „zmiana metaperspektywy”, nie jest jedynie zgrabnym zabiegiem semantycznym czy korektą myślenia o starości. Chodzi tu o paradygmatyczne przesunięcie z gerontologii pozytywistycznej ku gerontologii fenomenologicznej, czyli o radykalną zmianę w postrzeganiu świata przez jednostkę. Akcent zostaje przesunięty z troski o sprawy przyziemne na troskę o wartości uniwersalne ${ }^{29}$. Naturalną konsekwencją przyjęcia tej nowej (meta)perspektywy w spojrzeniu na funkcjonowanie osoby starszej jest m.in. ujmowanie zachowania jednostki już nie w kategoriach funkcjonalnego instrumentu służącego opanowaniu nowej sytuacji - strategii radzenia sobie z trudną rzeczywistością, ale jako (jakościowo) nowej właściwości rozwojowej, typowej dla okresu późnej dorosłości i tłumaczącej różnice w zakresie definiowania rzeczywistości zachodzące między osobami młodymi oraz tymi, którzy osiągnęli już wiek senioralny ${ }^{30}$.

Uchwycenie tej różnicy uznaje L. Tornstam za konieczny warunek akademickiej debaty nad strukturą (etapami) i dynamiką procesu adaptacji osoby do starości - dojrzewania ku gerotranscendencji ${ }^{31}$. Jeden ze swych początkowych artykułów dotyczących omawianej tu koncepcji szwedzki uczony zatytułował: The Quo Vadis of Gerontology: On the Scientific Paradigm of Gerontology. W publi-

${ }^{27}$ L. ToRnstam, Gerotranscendence: A Developmental Theory, 35.

28 TenżE, Gerotranscendence: a metatheoretical reformulation, 60.

29 Tenże, Gerotranscendence: A Developmental Theory, 35-43.

${ }^{30}$ Tamże, 36-37.

${ }^{31}$ L. ToRnstam, Maturing into Gerotranscendence, „The Journal of TransPersonal Psychology" 43 (2011) 2, 166-180. 
kacji tej zwrócił uwagę, iż obserwowane współcześnie wyraźne ukierunkowanie społeczeństwa Zachodu na wartości utylitarne odnajduje swe odzwierciedlenie także na płaszczyźnie naukowej gerontologii. Przejawia się to m.in. powszechną pogardą dla słabości i zależności oraz nadawaniem priorytetu takim cechom, jak: produktywność, użyteczność, wydajność i niezależność ${ }^{32}$. W konsekwencji ludzi starszych niesłusznie postrzega i ocenia się z perspektywy specyfiki średniej dorosłości, oczekując od nich witalności, samowystarczalności i efektywności w działaniu. Lars Tornstam stwierdza wprost: „Narzucamy osobom starszym nasze własne teorie zależne od wartości, co jednocześnie oznacza, że odchylenia od teoretycznych prognoz uznaje się za coś anormalnego, patologicznego" ${ }^{33}$. Innymi słowy, podejmowanie problematyki starzenia się i starości w ramach paradygmatu pozytywistycznego nie tylko zniekształca (zubaża) obraz człowieka w jesieni życia, ale także (a może przede wszystkim) ,spycha” go z obszaru normy w kierunku patologii ( $w$ ramach tego podejścia gerotranscendentne wycofanie identyfikowane jest najczęściej z objawami zaburzeń depresyjnych). Wobec powyższego autor postuluje, aby w akademickich rozważaniach nad starością bazować na myśleniu eksperymentalnym z odmiennym paradygmatem metateoretycznym. Propozycja nowej teorii pozytywnego starzenia się jest wyjściem naprzeciw tego postulatu ${ }^{34}$.

W tym miejscu rodzi się pytanie: Co kryje się za wyrażeniem „odmienny paradygmat metateoretyczny”,.. W celu opisu i zwięzłej charakterystyki tego technicznego terminu L. Tornstam odwołuje się do filozofii Wschodu. Warto w tym kontekście przywołać dosłowną wypowiedź autora:

Aby znaleźć drogę do nowego paradygmatu metateoretycznego, odejdziemy od zwykłego pozytywistycznego sposobu myślenia i zamiast tego skręcimy w egzotyczną i dziwną drogę oferowaną przez filozofię Wschodu. Skonfrontujemy nasze postrzeganie świata z tym, które prawdopodobnie charakteryzuje buddystę zen. Nie oznacza to jednak w żadnej mierze propagowania tej filozofii, jak błędnie zostało to ocenione przez niektórych (np. Jonsson i Magnusson, 2001). Jest to jedynie przykład odwrócenia naszego zwykłego sposobu myślenia w celu uzyskania nowego spojrzenia - technika sugerowana już wcześniej w niniejszej publikacji. A więc jest to myślenie eksperymentalne, oparte na domysłach, jak buddysta zen może konstruować swój świat ${ }^{35}$.

32 TENŻE, The quo vadis of gerontology; on the gerontological research paradigm. „The Gerontologist" 32 (1992) 3, 318-326.

33 Tamże, 322.

34 TenżE, Gerotranscendence: A Developmental Theory, 37-43.

35 Tamże, 37. 
W przytoczonym fragmencie L. Tornstam sugeruje, iż trafną metaforą, obrazującą nowy sposób myślenia i mówienia o starości i człowieku starym, jest metafora buddysty Zen. Snując dalej swoją refleksję, stwierdza on:

Buddysta zen prawdopodobnie żyje w ramach kosmicznego paradygmatu, w którym wiele granic jest rozproszonych i przenikalnych. Patrzy on pewnie na mieszkańców Zachodu jako ograniczonych i uwięzionych w obsesyjne i materialistyczne ramy. Kiedy my z kolei, posługując się naszą metateoretyczną perspektywą, obserwujemy buddystę zen zatraconego w medytacji, istnieje prawdopodobieństwo, że określimy go mianem „wycofanego”. Z pewnością tak byśmy uczynili, gdybyśmy nie wiedzieli, że jest on buddystą zen. Jednak, z metaperspektywy buddysty zen, wycofanie się nie ma z tym nic wspólnego. Żyje on bowiem w świecie, który definiowany jest inaczej niż nasz. W świecie tym wiele różnic między podmiotem a przedmiotem jest zamazanych. Twierdzenia buddysty zen są często trudne do zrozumienia z punktu widzenia naszego meta-teoretycznego paradygmatu, np. twierdzenie, że ja i ty nie jesteśmy odrębnymi obiektami, ale raczej jesteśmy częściami tej samej całości. Przeszłość, teraźniejszość i przyszłość również nie są odrębne, ale występują jednocześnie ${ }^{36}$.

Spojrzenie na proces starzenia się z perspektywy nowego paradygmatu, którego założenia ogniskują się $\mathrm{w}$ teorii gerotranscendencji, umożliwia $\mathrm{z}$ jednej strony spojrzenie na starość jako etap życia, w którym istnieje realna szansa rozwoju, z drugiej zaś uchwycenie konkretnych zmian rozwojowych ${ }^{37}$. Zmiany te porządkuje L. Tornstam wokół trzech głównych wymiarów (poziomów): (1) wymiaru kosmicznego (cosmic dimension) - dotyczącego zmian na poziomie egzystencjalnym i duchowym; (2) wymiaru odnoszącego się do Ja (self dimension) - obejmującego zmiany w sposobie postrzegania swojego obecnego Ja oraz Ja widzianego z perspektywy czasu; (3) wymiaru związanego z relacjami społecznymi (social and personal relationships dimension) - akcentującego więzi interpersonalne podtrzymywane przez jednostkę ${ }^{38}$. Ich zwięzłą charakterystykę zaprezentowano w tabeli 1 .

${ }^{36}$ L. TORnSTAM, Gerotranscendence: a metatheoretical reformulation, 37.

${ }^{37}$ Por. B. Wadensten, Introducing Older People, 381.

${ }^{38}$ L. TORnSTAM, Gerotranscendence - a theory about maturing into old age, ,Journal of Aging and Identity" 1 (1996), 37-50. 
Tabela 1

Zmiany dokonujące się $\mathrm{w}$ procesie gerotranscendencji ${ }^{39}$

\section{Teoria gerotranscendencji w ogniu krytyki}

\begin{tabular}{|c|c|c|}
\hline $\begin{array}{c}\text { Wymiar } \\
\text { gerotrans- } \\
\text { cendencji }\end{array}$ & Obszar zmian & Obserwowane zmiany \\
\hline \multirow{3}{*}{$\begin{array}{r}\text { Kosmiczny } \\
\text { (duchowy) }\end{array}$} & $\begin{array}{c}\text { Czas i dzieciń- } \\
\text { stwo }\end{array}$ & 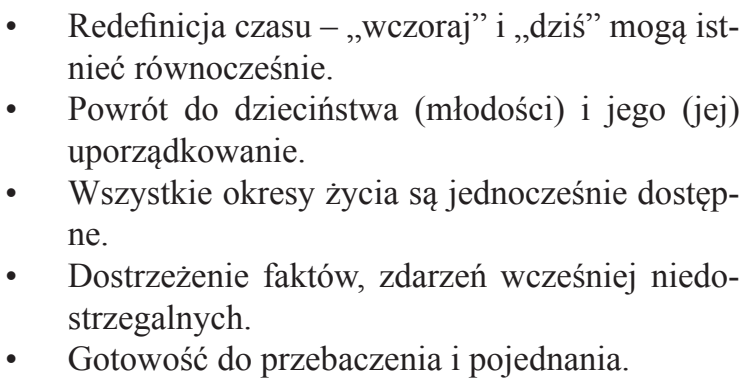 \\
\hline & $\begin{array}{c}\text { Relacje mię- } \\
\text { dzypokolenio- } \\
\text { we }\end{array}$ & 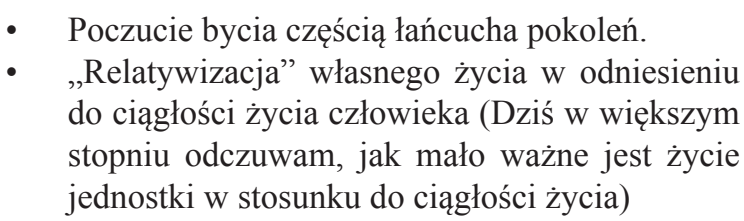 \\
\hline & Życie i śmierć & $\begin{array}{l}\text { - } \quad \text { Bardzo spokojne i czasami intrygujące sposoby } \\
\text { mówienia o życiu i śmierci. } \\
\text { - Transcendencja dualizmu życie - śmierć (Dziś } \\
\text { czuję, że granica pomiędzy życiem a śmiercią } \\
\text { jest mniej uderzająca w porównaniu do tego, jak } \\
\text { ją postrzegałem w wieku } 50 \text { lat). } \\
\text { - Akceptacja tajemniczego wymiaru życia-zgoda na } \\
\text { nieprzewidywalność, akceptacja dwuznaczności. } \\
\text { Doświadczanie radości z życia - docenianie naj- } \\
\text { mniejszych szczegółów codzienności, cieszenie } \\
\text { się tym, co się osiągnęło. }\end{array}$ \\
\hline
\end{tabular}

39 Opracowanie własne na podstawie: L. ToRnstam, Maturing into, 169-173. 


\begin{tabular}{|c|c|c|}
\hline \multirow{3}{*}{$\begin{array}{c}\text { Osobo- } \\
\text { wościowy } \\
(\text { Self })\end{array}$} & Obraz siebie & $\begin{array}{l}\text { - Jednostka wraca pamięcią do wcześniejszych } \\
\text { okresów swojego życia i odkrywa ukryte aspek- } \\
\text { ty własnego Ja-zarówno dobre, jak i złe. } \\
\text { - Nowa świadomość siebie oraz opór przed doko- } \\
\text { nywaniem projekcji swoich „ciemnych” stron } \\
\text { (braków, niedoskonałości, porażek) na innych. }\end{array}$ \\
\hline & $\begin{array}{l}\text { Stosunek do } \\
\text { samego siebie }\end{array}$ & $\begin{array}{l}\text { - Spadek egocentryzmu. } \\
\text { - Jednostka doświadcza nowej świadomości tego, } \\
\text { że nie jest centrum wszechświata. } \\
\text { - Większa pewność siebie. } \\
\text { - Wzrost poczucia własnej wartości. } \\
\text { Koncentracja (nadmiarowa) na ciele i jego pięk- } \\
\text { nie zostaje zastąpiona akceptacją własnej cieles- } \\
\text { ności. }\end{array}$ \\
\hline & $\begin{array}{c}\text { Integralność } \\
\text { Ego }\end{array}$ & $\begin{array}{l}\text { - Jednostka zauważa, jak uwaga skupiona na } \\
\text { własnych potrzebach została stopniowo zastą- } \\
\text { piona uwagą skupioną na potrzebach innych, } \\
\text { w szczególności dzieci i wnucząt. } \\
\text { - Egoizm ustępuje miejsce na rzecz altruizmu. } \\
\text { - Redefinicja rzeczywistości - przeszłe życie zo- } \\
\text { staje „wpasowane” w nowe ramy odniesienia. }\end{array}$ \\
\hline
\end{tabular}




\begin{tabular}{|c|c|c|}
\hline \multirow{5}{*}{$\begin{array}{c}\text { Relacji } \\
\text { społecz- } \\
\text { nych } \\
\text { (społeczny) }\end{array}$} & $\begin{array}{l}\text { Relacje inter- } \\
\text { personalne }\end{array}$ & $\begin{array}{l}\text { - Zanika (nadmierne) zainteresowanie nawiązywa- } \\
\text { niem i podtrzymywaniem powierzchownych rela- } \\
\text { cji towarzyskich. } \\
\text { - Wcześniejsze zainteresowanie obcowaniem } \\
\text { wśród innych ustępuje na rzecz chęci przebywa- } \\
\text { nia w towarzystwie konkretnego przyjaciela lub } \\
\text { pozostania w domu i oddania się medytacji. } \\
\text { - Zwiększona potrzeba pozytywnej samotności } \\
\text { kontemplacyjnej. } \\
\text { - Skupienie się na własnym wewnętrznym świe- } \\
\text { cie. }\end{array}$ \\
\hline & Role społeczne & $\begin{array}{l}\text { - Jednostka zaczyna rozumieć różnicę pomiędzy } \\
\text { własnym Ja a rolami, jakie odgrywa w życiu. } \\
\text { - Odczuwanie silnej chęć ich porzucenia i wyjścia } \\
\text { poza nie w celu zbliżenia się do swojego praw- } \\
\text { dziwego Ja. } \\
\text { - Wzrost rozumienia bądź nowa pokrzepiająca } \\
\text { świadomość tego, dlaczego odgrywanie ról było } \\
\text { w życiu potrzebne. }\end{array}$ \\
\hline & $\begin{array}{l}\text { Społeczne } \\
\text { konwencje } \\
\text { i normy }\end{array}$ & $\begin{array}{l}\text { - Jednostka nabywa umiejętność przekraczania } \\
\text { niepotrzebnych konwencji, norm i zasad, które } \\
\text { wcześniej ograniczały jej wolność wyrażania } \\
\text { siebie. } \\
\text { - Zmniejszenie obaw oraz lęku przed ekspozycją } \\
\text { społeczną i opinią innych. }\end{array}$ \\
\hline & $\begin{array}{l}\text { Potrzeby ży- } \\
\text { ciowe }\end{array}$ & $\begin{array}{l}\text { - Ascetyzm w zakresie własnych potrzeb - poja- } \\
\text { wienie się zrozumienia, że ostatnia część podró- } \\
\text { ży przez życie jest łatwiejsza i bardziej radosna, } \\
\text { jeśli bagaż jest lekki. } \\
\text { - Gotowość do przekazania własnych rzeczy dzie- } \\
\text { ciom, wnuczętom lub innym ludziom. } \\
\text { Zmniejszenie przywiązania do dóbr material- } \\
\text { nych. }\end{array}$ \\
\hline & $\begin{array}{c}\text { Życiowa mą- } \\
\text { drość }\end{array}$ & $\begin{array}{l}\text { - Zbytnia pewność siebie w rozróżnianiu pomię- } \\
\text { dzy tym, co słuszne a tym, co niewłaściwe, po- } \\
\text { między dobrem a złem, ustępuje na rzecz rozu- } \\
\text { mienia, że w rzeczywistości odpowiedź rzadko } \\
\text { jest prosta. } \\
\text { - Zauważalna staje się niechęć do powierzchow- } \\
\text { nego oddzielania dobra od zła, a tym samym po- } \\
\text { wstrzymywanie się od wydawania sądów i udzie- } \\
\text { lania porad. } \\
\text { Przekroczenie dualizmu dobro - zło skutkuje } \\
\text { większą otwartością umysłu i tolerancją. }\end{array}$ \\
\hline
\end{tabular}




\section{Teoria gerotranscendencji w ogniu krytyki}

Opisywana w prezentowanym artykule teoria pozytywnego starzenia się była dotychczas weryfikowana w wielu badaniach zarówno o charakterze jakościowym, jak i ilościowym. Badania te były prowadzone głównie w kręgu krajów skandynawskich, choć nie tylko ${ }^{40}$. Przegląd literatury gerontologicznej ostatniej dekady minionego stulecia wyraźnie sugeruje, iż teoria gerotranscendencji bardzo szybko zyskała uznanie środowiska akademickiego i była traktowana jako jedna z kluczowych teorii psychologicznych dotyczących problematyki starzenia się i starości ${ }^{41}$. Dość wspomnieć, że publikacje L. Tornstama z 1994 r. (Psychologia społeczna starzenia ${ }^{42}$ ) i 2005 r. (Gerotranscendencja: Teoria pozytywnego starzenia się $^{43}$ ) w niedługim czasie stały się jednymi z najważniejszych podręczników w zakresie gerontologii społecznej w Skandynawii. Ponadto propozycja L. Tornstama została wyraźnie wyakcentowana przez Joan Erikson w poprawionym i uzupełnionym wydaniu książki Erika Eriksona zatytułowanej: Dopetniony cykl życia (The Life Cycle Completed), której ostatni rozdział autorka poświęciła wyłącznie koncepcji L. Tornstama ${ }^{44}$.

Teoria gerotranscendencji doczekała się także krytycznych opracowań. W pierwszej kolejności oponenci L. Tornstama zwracają uwagę na sprzeczne wyniki badań empirycznych, które były prowadzone w oparciu o główne założenia teorii gerotranscendencji. Uzyskane rezultaty ujawniły bowiem, że: (1) poziom gerotranscendentnych zmian nie zwiększał się w podeszłym wieku; (2) nie zaobserwowano zakładanych gerotranscendentnych zmian w niektórych obszarach funkcjonowania seniorów (np. percepcja czasu, potrzeby materialne, lęk przed śmiercią, jakość życia, pozytywne versus negatywne aspekty własnego Ja); (3) dodatnia korelacja pomiędzy wiekiem a gerotranscendencją nie potwierdziła podstawowego założenia teorii, że wiek podeszły jest jakościowo różny od wieku średniego. Przywołane zarzuty, zdaniem niektórych, pozwalają uznać, że teoria gerotranscendencji w niewielkim stopniu spełnia kryterium falsyfikowalności ${ }^{45}$.

Krytyce poddano również zaproponowaną dla zilustrowania teorii gerotranscendencji (w jej warstwie paradygmatycznej) metaforę buddysty zen. Adwersarze omawianej teorii twierdzą, że L. Tornstam tworząc podwaliny pod własną koncep-

\footnotetext{
40 Zob. P. BRUdeK, Podmiotowe korelaty satysfakcji z matżeństwa, 142-171.

${ }^{41}$ J. Schroots, Theoretical development in the psychology of aging, „The Gerontologist" 36 (1996) 6, 742-748.

${ }^{42}$ L. ToRnstam, Aldrandets socialpsykologi, Stockholm 1994.

${ }^{43}$ Tenże, Gerotranscendence: A Developmental Theory of Positive Aging, New York 2005.

${ }^{44}$ E.H. Erikson, J.M. ERIKSOn, Dopetniony cykl życia.

${ }^{45}$ H. Jönson, J.A. MAGnusson, A new age of old age?: Gerotranscendence and the re-enchantment of aging, ,Journal of Aging Studies” 15 (2011) 4, 322-324.
} 
cję, pozostawał, podobnie jak wielu współczesnych badaczy Europy Zachodniej i Stanów Zjednoczonych, pod wpływem filozofii japońskiego naukowca buddysty, Daisetsu Teitaro Suzukiego (1870-1966). Autor ten przedstawił zen w kategoriach swoistej mądrości analizowanej w oderwaniu od jej japońskich założeń religijnych, filozoficznych i społeczno-politycznych. Dla opisu zen posłużył się natomiast koncepcjami odnoszącymi się do współczesnej psychologii (psychoanalizy, psychologii humanistycznej), darwinizmu i niemieckiego idealizmu. Elementy niezależnej od jakichkolwiek uwarunkowań idei zen D. Suzukiego można dziś z łatwością odnaleźć w różnych naukach współczesnego ruchu New Age ${ }^{46}$. Warto w tym miejscu podkreślić, że sam L. Tornstam odcina się od religijno-filozoficznych konotacji zastosowanej metafory buddysty zen, twierdząc, że służy ona wyłącznie zobrazowaniu analizowanego przez niego zjawiska ${ }^{47}$.

Teorii gerotranscendencji zarzucano również to, iż stała się kolejną próbą ,zaczarowania" starości. Zarzut ten skupia się głównie na swego rodzaju populizmie gerotranscendencji, który wyraża się w powszechnej niezgodzie modernistycznego świata na słabą i pełną ułomności starość. Warto w tym kontekście przywołać wypowiedź głównych oponentów teorii gerotranscendencji:

(...) współczesne społeczeństwo zachodnie od społeczeństwa tradycyjnego odróżnia racjonalizm i sekularyzm. W unaukowianiu i profesjonalizacji ludzkich przedsięwzięć zignorowano kwestie egzystencjalne, co doprowadziło do odczarowania świata. Sugerujemy tutaj, że gerotranscendencja wpływa na gerontologię ze względu na to, że oferuje nową, ponownie „zaczarowaną” perspektywę postrzegania zracjonalizowanego i sprofesjonalizowanego procesu współczesnego starzenia się. (...). W tym sensie teoria gerotranscendencji stanowi rozwiązanie jednego z najbardziej fundamentalnych problemów starzenia się we współczesnym świecie - znalezieniem w wieku podeszłym pozytywnego wymiaru, który nie stoi w sprzeczności z degradacją intelektualną czy fizyczną oraz uzależnieniem od pomocy innych ${ }^{48}$.

Pod adresem L. Tornstama i proponowanej przez niego teorii kierowano także zarzut medykalizacji wieku podeszłego. Lekarze i pielęgniarki mogą zalecać medytacje i terapię, aby „chorzy” (seniorzy) mogli osiągnąć optymalny rozwój albo skutecznie kompensować ujawnione deficyty intelektualne. Gerotranscendencja zakłada, że zwieńczeniem procesu dojrzewania w starości jest ujawnienie się nowej jakości w postaci mądrości ${ }^{49}$. Wyniki współczesnych badań pro-

\footnotetext{
46 Tamże, 324-326.

${ }^{47}$ L. Tornstam, Gerotranscendence: A Developmental Theory, 37.

${ }^{48}$ H. Jönson, J.A. Magnusson, A new age of old age?, 326.

49 Tamże, 327-328.
} 
wadzonych w obszarze mądrości przekonują, że wiek nie jest wystarczającym czynnikiem wzrostu mądrości ${ }^{50}$. W konsekwencji trzeba podejmować starania nad pobudzaniem tej pożądanej właściwości osobowościowej. Jej brak bowiem, zdaniem adwersarzy, kojarzony jest (może być) z chorobą ${ }^{51}$.

Przywołane wyżej zarzuty formułowane przez niektórych badaczy na łamach prestiżowych czasopism z zakresu gerontologii i psychologii starzenia się (,„Journal of Aging Studies") pod adresem teorii gerotranscendencji nie dyskredytują naukowego waloru tej koncepcji. Należy je raczej odczytywać jako zachętę do dalszej naukowej eksploracji leżących u podstaw zaproponowanej przez L. Tornstama idei pomyślnego starzenia się. Autorzy krytycznie odnoszący się do gerotranscendencji w konkluzji swoich analiz stwierdzają:

Pomimo swoich wad i niejednoznaczności teoria gerotranscendencji wciąż zyskuje na popularności, a w kilku krajach zachodnich jest wymieniana jako potencjalna teoria pielęgniarstwa. Skąd więc jej urok? Współczesny model państwa opiekuńczego umożliwia wielu osobom starszym przejście na emeryturę w dobrym zdrowiu i z zachowaniem bezpieczeństwa finansowego. $\mathrm{Z}$ drugiej strony wiek podeszły staje się coraz większym problemem społecznym, a zawody z nim związane, jak i sami ludzie starsi szukają przeciwstawnych wyobrażeń i nowatorskich podejść do wieku podeszłego i opieki. Próba ponownego zaczarowania starzenia się odrobiną „orientu”, podjęta przez teorię gerotranscendencji, wydaje się specjalistom i wielu gerontologom intrygująca i inspirująca, gdyż stanowi powiew świeżości w ich pracy. Dla wielu osób starszych teoria gerotranscendencji prawdopodobnie może okazać się pomocna, jeśli chodzi o wzbogacenie ich życia osobistego.

Uważamy, że głównym problemem rzeczonej teorii jest jej esencjalizm. (...) Aby starzeć się we „właściwy” sposób, każdy rozwijający się człowiek musi jej doświadczyć. (...) Ponadto Tornstam (1992) dążył do zerwania z normatywną tradycją gerontologiczną (...). Problemy związane z podejściem normatywnym stają się widoczne w kontekście opieki i pielęgniarstwa, gdzie esencjalizm teorii gerotranscendencji stwarza ryzyko niedostrzeżenia zróżnicowania zainteresowań i potrzeb osób w podeszłym wieku oraz postrzegania osób niewykazujących transcendencji za odstępstwo od normy. Teoretycznie rozwiązaniem może być przejście do gerontologii postmodernistycznej, w której podkreśla się znaczenie wieku podeszłego jako zjawiska kulturowego i kontekstowego (Cole

${ }^{50}$ Zob. M. Ardelt, Wisdom, age, and well-being, 279-291; P. Baltes, J. Gluck, U. Kunzmann, Mądrość. Jej struktura i funkcja w kierowaniu pomyślnym rozwojem w okresie całego życia, w: J. CzAPIŃSKI (red.), Psychologia pozytywna, Warszawa 2004, 117-146; S. STEUDEN, Wybrane psychologiczne aspekty procesu starzenia się i starości, w: M. Cybulski, E. KRAJEWsKa-KuŁaK, N. WaszKIEWICZ, K. Kf̨iziora-Kornatowska (red.), Psychogeriatria, Warszawa 2017, 299-312; S. Steuden, Madrość jako efekt integracji doświadczeń życiowych, w: M. ADAMczYK (red.), Starość. Między tradycja a wspótczesnością, Kraków 2016, 24-38.

${ }^{51}$ H. Jönson, J. A. MAgnusson, A new age of old age?, 328. 
i in., 1992). Stąd zalecamy, żeby nie traktować teorii gerotranscendencji jako teorii, czym faktycznie jest wiek podeszły, lecz czym może się stać52.

Podsumowując powyższy wywód, warto podkreślić niekwestionowane walory koncepcji L. Tornstama i przywołać te aspekty gerotranscendencji, które budzą na dziś pewne wątpliwości, ale tym samym poszerzają przestrzeń akademickiej debaty. Wśród mocnych stron tej teorii wskazuje się przede wszystkim na to, że: (1) odnosi się ona do realnych doświadczeń starszych osób; (2) podkreśla znaczenie teorii w doświadczeniu starości; (3) stwarza nową perspektywę w spojrzeniu na rozwój osób starszych; (4) ma wyraźne zastosowanie głównie w praktyce zdrowotnej dotyczącej osób w wieku podeszłym; (5) umożliwia personelowi medycznemu zrozumienie zachowań seniorów i stanowi ramy odniesienia dla promowania pozytywnego starzenia się ${ }^{53}$.

Z kolei do mankamentów koncepcji L. Tornstama zalicza się przede wszystkim: (1) brak jednoznacznej definicji gerotranscendencji - autor jedynie wskazuje na szczegółowe cechy gerotranscendentnego procesu; (2) kontrowersje wokół założeń metodologicznych oraz niespójności rezultatów zrealizowanych badań; (3) ograniczenie gerotranscendencji do starości, podczas gdy inni badacze dowiedli, że proces ten dokonuje się w całej rozciągłości życia; (4) fakt, iż teoria wyjaśnia procesy zmian jedynie na poziomie indywidualnym i nie uwzględnia w dostatecznym stopniu czynników społecznych, które mogą mieć wpływ na przebieg starzenia się $e^{54}$.

\section{Zakończenie}

Opisana w prezentowanym artykule teoria gerotranscendencji autorstwa L. Tornstama, rozwijana głównie w krajach skandynawskich, pomimo iż wzbudza pewne kontrowersje, stanowi poznawczo wartościową i inspirującą koncepcję pozytywnego starzenia się. Mając na uwadze zarówno mocne, jak i słabe strony koncepcji gerotranscendencji należy założyć, że teoria L. Tornstama pozwala przyjąć nową perspektywę w spojrzeniu na psychospołeczne funkcjonowanie osób w okresie późnej dorosłości. Stwarza ona bowiem teoretyczne podstawy do poszukiwania potencjalnych predyktorów proaktywnego starzenia się. Odsłania także potencjał, jaki drzemie w ostatnim, wciąż niedocenianym, etapie życia czło-

52 Tamże, 328-329.

53 F. Rajani, H. Jawaid, Theory of Gerotranscendence: An Analysis, „Austin Journal of Psychiatry and Behavioral Sciences" 2 (2015) 1, 1036.

54 Tamże. 
wieka. Uwzględniając walory aplikacyjne teorii oraz religijno-kulturową specyfikę Polski (i Europy), warto w przyszłości zrealizować projekt badawczy, którego celem byłaby interpretacja gerotranscendencji w terminach teologii katolickiej, prawosławnej czy protestanckiej.

\section{Bibliografia}

Ardelt Monika, Wisdom, age, and well-being, w: K.W. Schaie, S.L. Willis (red.), Handbook of the psychology of aging, Amsterdam: Elsevier 2011, s. 279-291.

Baltes Paul, Baltes Margret, Psychological perspectives on successful aging: The model of selective optimization with compensation, „Successful aging: Perspectives from the Behavioral Sciences" 1 (1990) 1, s. 1-34.

Baltes Paul, Dittmann-Kohli Freya, Dixon Roger, New perspectives on the development of intelligence in adulthood: Toward a dual-process conception and a model of selective optimization with compensation, „Life-Span Development and Behavior" 6 (1984), s. 33-76.

Baltes Paul, Glück Judith, Kunzmann Ute, Mąrość. Jej struktura i funkcja w kierowaniu pomyślnym rozwojem w okresie całego życia, w: J. CZAPIŃSKI (red.), Psychologia pozytywna, Warszawa: PWN 2004, s. 117-146.

Brudek Pawet, Ciula Grzegorz, Hierarchia wartości a satysfakcja ze zwiazku matżeńskiego u osób w okresie późnej dorostości, „Śląskie Studia Historyczno-Teologiczne" 46 (2013) 2, s. 368-382.

Brudek Pawee, Larsa Tornstama Teoria Gerotranscendencji jako teoria pozytywnego starzenia się, „Psychologia Rozwojowa” 21 (2016) 4, s. 9-25.

BRudek Pawet, Podmiotowe korelaty satysfakcji z matżeństwa osób $w$ okresie późnej dorostości, Lublin 2015 (praca dr. w BKUL).

BRUdeK PAwet, Rola dziadków w procesie wspierania rozwoju dziecka $w$ prenatalnym okresie życia z perspektywy teorii gerotranscendencji Larsa Tornstama, w: E. Lichtenberg-Kokoszka, E. Janiuk, P. Kierpal (red.), Prenatalny okres życia człowieka. Zagadnienie interdyscyplinarne, Kraków: Wydawnictwo „Impuls” 2014, s. 109-126.

Brudek Pawex, Steuden Stanistawa, Religijne korelaty zadowolenia z matżeństwa $w$ okresie późnej dorostości, w: P. BRUdeK, S. STEUden, I. JANUSzewSKa, A. Gamrowska (red.), Oblicza starości we wspótczesnym świecie. Perspektywa psychologiczno-medyczna, Lublin: Wydawnictwo KUL 2015, s. $15-44$.

Brudek Pawee, Steuden Stanistawa, Wstęp, w: P. Brudek, S. Steuden, I. Januszewska, A. Gamrowska (red.), Oblicza starości we wspótczesnym świecie. 
Perspektywa psychologiczno-medyczna, t. I, Lublin: Wydawnictwo KUL 2015, s. 7-11.

Carstensen Laura, Social and emotional patterns in adulthood: support for socioemotional selectivity theory, „Psychology and Aging” 3 (1992), s. 331338.

Florczyk Łukasz, Brudek Pawel Steuden Stanistawa, Madrość jako przymiot starości. Perspektywa biblijna, „Forum Teologiczne” 17 (2016), s. 55-71.

Jönson HÅkan, Magnusson Jan ARne, A new age of old age?: Gerotranscendence and the reenchantment of aging, „Journal of Aging Studies” 15 (2011) 4, s. $317-331$.

Lewin Fereshteh Ahmadi, Thomas Eugene, Gerotranscendence and Life Satisfaction: Studies of Religious and Secular Iranians and Turks, ,Journal of Religious Gerontology" 12 (2001) 1, s. 17-41.

Liang Jaylene, Components of a Meaningful Retirement Life - A Phenomenological Study of the $1950^{s}$ Birth Cohort in Urban China, ,Journal of cross-cultural gerontology" 26 (2011) 3, s. 279-298

Malec Malgorzata, Gerotranscendencja - teoria pozytywnego starzenia się. Założenia i znaczenie, w: M. OleJARz (red.), Dyskursy młodych andragogów, Zielona Góra: Oficyna Wydawnicza Uniwersytetu Zielonogórskiego 2012, s. $45-60$.

Quinodoz Danielle, Starzenie się - przygoda życia, która trwa, thum. M. Kaczorowska- Korzniakow, Warszawa: Oficyna Ingenium 2014.

Raclaw Mariola, Rosochacka-Gmitrzak Marzena, Proces starzenia sie, w kontekście wyzwań demografii, polityki społecznej oraz doniesień badawczych, Warszawa: Ministerstwo Pracy i Polityki Socjalnej 2012.

Rajani Fahreen, Jawaid Hena, Theory of Gerotranscendence: An Analysis, „Austin Journal of Psychiatry and Behavioral Sciences" 2 (2015) 1, s. 10351038.

Ridder-Symoens HiLde, A History of the University in Europe, Cambridge: University Press 2003.

Schroots Johannes, Theoretical development in the psychology of aging, „The Gerontologist" 36 (1996) 6, s. 742-748.

Steuden StanisŁawa, Brudek Pawee, Florczyk Łukasz, Mądrość jako efekt pozytywnego starzenia się. Perspektywa psychologiczna, „Forum Teologiczne” 17 (2016), s. 73-87.

Steuden StanisŁawa, Mąrość jako efekt integracji doświadczeń życiowych, w:

M. AdAMcZYK (red.), Starość. Między tradycja a współczesnościa, Kraków:

Wydawnictwo „Impuls” 2016, s. 24-38.

Steuden StanisŁawa, Psychologia starzenia się i starości, Warszawa: PWN 2011. 
Steuden StanisŁaWA, Wybrane psychologiczne aspekty procesu starzenia się i starości, w: M. Cybulski, E. Krajewska-KuŁak, N. Waszkiewicz, K. KęDZIora-KornatowsKa (red.), Psychogeriatria, Warszawa: Wydawnictwo Lekarskie PZWL 2017, s. 299-312.

Steuden StanisŁawa, Z rozważań nad mądrościa, w: I. Ulfik-Jaworska, A. Gala (red.), Dalej w tę sama stronę. Księga Jubileuszowa dedykowana Profesor Marii Braun-Gatkowskiej, Lublin: Wydawnictwo KUL 2012, s. 533-548.

Straś-Romanowska Maria, Późna dorostość, w: J. Trempata (red.), Psychologia rozwoju człowieka, Warszawa 2011, s. 326-350.

Szymańczak Jolanta, Starzenie się polskiego społeczeństwa - wybrane aspekty demograficzne, „Studia BAS. Starzenie się społeczeństwa polskiego” 30 (2012) 2, s. 9-28.

ToRnstam Lars, Åldrandets socialpsykologi, Stockholm: Norstedts 1994.

TORNSTAM LARS, Gerotranscendence - a theory about maturing into old age, „Journal of Aging and Identity" 1 (1996), s. 37-50.

ToRnstam Lars, Gerotranscendence: A Developmental Theory of Positive Aging, New York: Springer Publishing Company 2005.

TORNSTAM LARS, Gerotranscendence: a metatheoretical reformulation of the disengagement theory, „Aging: Clinical and Experimental Research” 1 (1989) 1, s. 55-63.

Tornstam Lars, Maturing into Gerotranscendence, „The Journal of TransPersonal Psychology" 43 (2011) 2, s. 166-180.

TORnStAm LARs, The quo vadis of gerontology; on the gerontological research paradigm, „The Gerontologist” 32 (1992) 3, s. 318-326.

Wadensten Barbaro, Carlsson Marianne, The theory of gerotranscendence in practice: guidelines for nursing - Part II, „International Journal of Older People Nursing" 4 (2007) 2 (4), s. 295-301.

Wadensten Barbaro, Carlsson Marianne, Theory driven guidelines for practical care of older people, based on the theory of gerotranscendence, „Journal of Advanced Nursing" 41 (2003) 5, s. 462-470.

Wadensten Barbaro, Introducing Older People to the Theory of Gerotranscendence, ,Journal of Advanced Nursing” 52 (2005) 4, s. 381-388.

WADENSTEN BARBARO, The theory of gerotranscendence as applied to gerontological nursing - Part I, „International Journal of Older People Nursing” 4 (2007) 2, s. 289-294.

ZająC-LAMPARSKa LudMIEA, Wspomaganie funkcjonowania ludzi starzejacych sie, w: J. Trempata (red.), Psychologia rozwoju czlowieka, Warszawa: PWN 2011, s. 419-431. 